\title{
Effects of Pseudomonas putida S1Pf1Rif Against Chrysanthemum Yellows Phytoplasma Infection
}

\author{
Elisa Gamalero, Romina D’Amelio, Chiara Musso, Simone Cantamessa, Barbara Pivato, \\ Giovanni D’Agostino, Jin Duan, Domenico Bosco, Cristina Marzachì, and Graziella Berta
}

First, third, fourth, fifth, sixth, and tenth authors: Università del Piemonte Orientale "Amedeo Avogadro", Dipartimento di Scienze dell'Ambiente e della Vita, Viale Teresa Michel 11, Alessandria, 15121, Italy; second, fifth, and ninth authors: CNR, Istituto di Virologia Vegetale, Strada delle Cacce 73, Torino, 10135, Italy; seventh author: University of Waterloo, Department of Biology, 200 University Avenue West, Waterloo, ON N2L 3G1, Canada; and second and eighth authors: Università di Torino, Dipartimento di Valorizzazione e Protezione delle Risorse Agroforestali, Via Leonardo Da Vinci 44, Grugliasco (Torino) 10095, Italy.

Accepted for publication 9 April 2010.

\begin{abstract}
Gamalero, E., D’Amelio, R., Musso, C., Cantamessa, S., Pivato, B., D’Agostino, G., Duan, J., Bosco, D., Marzachi, C., and Berta, G. 2010. Effects of Pseudomonas putida S1Pf1Rif against chrysanthemum yellows phytoplasma infection. Phytopathology 100:805-813.

Phytoplasmas cause damage on a number of plant species leading to relevant economical loss. Up to now, strategies to limit their spread led to only partial success. In this context, the use of plant-beneficial bacteria to control phytoplasmas has never been explored. The aim of this work was to assess the effect of Pseudomonas putida S1Pf1Rif against chrysanthemum yellows phytoplasma (CYP) infection of daisy. Plant bio-

were evaluated in inoculated and control plants. CYP reduced plant growth and root development. Although the phytoplasma titer in young apical leaves was not affected by inoculation with S1Pf1Rif, the pseudomonad improved plant growth of CYP-infected plants. Whereas CYP titer increased over time in uninoculated plants, its viability decreased, regardless of the presence of $P$. putida S1Pf1Rif. Finally, phytoplasma cells in fully developed leaves of CYP-infected plants inoculated with S1Pf1Rif often appeared degenerated. Overall, our results indicate that $P$. putida S1Pf1Rif is able to alleviate the disease, although it does not affect the presence of viable phytoplasmas in young, developing leaves of the infected plants.
\end{abstract} mass, root architecture, symptom severity, phytoplasma titer, and viability
Phytoplasmas are wall-less pathogenic bacteria belonging to the class Mollicutes and associated with economically important diseases affecting fruit trees (pome fruit, stone fruit, coconut, and grape, among others), vegetables (such as lettuce, potato, tomato, and others), ornamentals (herbaceous trees and shrubs), and weeds, mostly causing proliferation, stunting, yellowing, and virescence or phyllody (4). They are phloem limited and transmitted in a persistent manner by leafhoppers, plant hoppers, and psyllids (54).

Chemical treatments against insects such as Scaphoideus titanus, vector of the quarantine flavescence dorée phytoplasma to grapevine, are required by law (36), with a negative impact on the environment and human health. Plant treatment with tetracycline against phytoplasma leads to temporary delay or symptom relief (56). However, following public concern about the possible spread of antibiotic resistance in the environment, the use of antibiotics for plant therapy is forbidden in most countries. Planting phytoplasma-free stocks is advisable but the control of insect vector populations is required to prevent infection during the vegetative season (36). Breeding of plant cultivars resistant to phytoplasma is providing an alternative approach to controlling some of these diseases (43). Finally, thermal treatment is also routinely applied to grapevine propagation material (49), although careful setting of operational procedures is required to avoid secondary effects on the vitality and productivity of the plants (31).

Corresponding author: G. Berta; E-mail address: graziella.berta@mfn.unipmn.it

doi:10.1094/PHYTO-100-8-0805

(c) 2010 The American Phytopathological Society
Bacteria living in the rhizosphere may influence plant growth and health by a number of mechanisms. Direct stimulation of plant growth is usually related to hormone (i.e., indole acetic acid [IAA]) synthesis (37), mineral nutrition improvement (i.e., phosphate solubilization or nitrogen fixation) $(24,53)$, and modifications of root architecture $(19,20)$. Indirect stimulation relies mainly on plant health improvement through the biocontrol of phytopathogens mediated by antibiotics, lytic enzymes, and siderophores (55); the enhancement of plant tolerance to environmental stress by the production of the enzyme 1-aminocyclopropane-1-carboxylate (ACC) deaminase; lowering stress ethylene levels in planta $(21,22)$; or triggering induced systemic resistance (ISR) $(27,52)$. Hence, the presence of beneficial rhizospheric microorganisms, able to increase plant tolerance to biotic stresses or to behave as biocontrol agents, may represent a valid alternative for controlling phytoplasma diseases. Despite the acknowledged role of soil bacteria as biocontrol agents against different phytopathogenic organisms $(3,8,28,44,45)$, information about the possible use of rhizospheric bacteria in the suppression of the phytoplasma diseases are completely lacking. To the best of our knowledge, only one paper dealing with the comparison of the culturable microflora on root systems of phytoplasma-tolerant and infected coconut palms hypothesized the possible role of the bacterial community in the suppression of a phytoplasma-induced disease (23).

Phytoplasma infection depends on the interactions among three partners: the plant, the pathogen, and the vector. The introduction of a fourth partner increases the complexity of the system. For this reason, we decided to use a model pathosystem represented by Chrysanthemum carinatum (Schousboe); chrysanthemum yellows phytoplasma (CYP); and its leafhopper vector, Macrosteles quadripunctulatus (Kirschbaum). CYP is a strain of the 
'Candidatus Phytoplasma asteris' phytoplasma (16Sr-IB) which infects a variety of dicotyledonous plants and is transmitted with different efficiencies by several species of leafhoppers that can be easily reared under controlled conditions (5). Due to its short incubation in the plant and latency in the vector, rapid and obvious symptom development and extremely high transmission efficiency, CY represents an optimal model system. Furthermore, a real-time polymerase chain reaction (PCR) method allowing the quantification of CYP DNA has been previously developed by our group (32) and applied to describe the colonization pattern of CYP inside the host plant (39).

The aim of this study was to determine the effects of a selected rhizospheric bacterium, with characterized physiological traits, on CYP-infected daisy plants. Plant health was evaluated by measuring symptom severity, plant development, and root architecture and discussed in relation to the quantitative determination of CYP titer and viability and to the qualitative description of phytoplasma cell morphology by transmission electron microscopy. In this context, a new method to estimate phytoplasma viability inside the plant was developed.

\section{MATERIALS AND METHODS}

Selection of the bacterial strain. Strain S1Pf1 was selected from $\approx 100$ bacterial strains belonging to fluorescent pseudomonads (Bacillus and Streptomyces groups) isolated from the soil next to a asymptomatic grapevine (Vitis vinifera L. cv. Barbera), among plants with clear symptoms of phytoplasma infection, in a vineyard located in Bruno (Asti, Italy). This environment was chosen based on the basic idea that the microflora associated with an asymptomatic grapevine, in a context where the disease is present, may contribute to support the growth of the plant. All the isolated strains were identified by Biolog assay and characterized for their physiological activities. A preliminary assay to evaluate plant protection against phytoplasma disease according to the plant symptoms was performed using 10 strains selected for their physiological traits. Among them, three strains were selected for a second preliminary assay to characterize both plant health and growth parameters. The S1Pf1 strain was the most performant and, therefore, was selected for further studies (11). A rifampicin spontaneous-resistant mutant (S1Pf1Rif) was obtained by plating on King's B (KB) medium (Fluka, Milan, Italy) supplemented with rifampicin $\left(100 \mu \mathrm{g} \mathrm{ml}^{-1}\right)$ (Fluka). Cultures of bacterial cells, grown in Luria-Bertani (LB) broth medium supplemented with antibiotic, were stored at $-80^{\circ} \mathrm{C}$ in $50 \%$ glycerol.

Bacterial identification. The genomic DNA of strain S1Pf1 was extracted using the Wizard Genomic DNA purification kit (Promega, ON, Canada). Briefly, $1 \mathrm{ml}$ of overnight culture was centrifuged at $14,000 \mathrm{rpm}$ for $1 \mathrm{~min}$. The pellet was added to $600 \mu \mathrm{l}$ of Nuclei Lysis Solution and incubated at $80^{\circ} \mathrm{C}$ for $5 \mathrm{~min}$, and the suspension was treated with $3 \mu$ of RNase solution and $200 \mu \mathrm{l}$ of Protein Precipitation Solution. After centrifugation, the supernatant was added to $600 \mu \mathrm{l}$ of isopropanol and centrifuged at $14,000 \mathrm{rpm}$ for $2 \mathrm{~min}$. DNA was washed with $70 \%$ ethanol, air dried, and resuspended in $100 \mu \mathrm{l}$ of DNA Rehydration Solution. PCR amplification of 16S rDNA was performed by using the primers SPf5 (5'-GGACGGGTGAGTAATGCC-3') and SPf3 (5'CCCTACGGCTACCTTGTTAC-3'). The PCR reaction was carried out with KOD Hot Start DNA Polymerase as follows: $95^{\circ} \mathrm{C}$ for $2 \mathrm{~min} ; 30$ cycles of $95^{\circ} \mathrm{C}$ for $20 \mathrm{~s}, 58^{\circ} \mathrm{C}$ for $15 \mathrm{~s}$, and $70^{\circ} \mathrm{C}$ for $40 \mathrm{~s}$; and $70^{\circ} \mathrm{C}$ for $5 \mathrm{~min}$ as the final extension time. The amplified PCR product was extracted from agarose gel, purified with Wizard SV Gel and PCR Clean-up System (Promega, ON, Canada), and sent to York University for sequencing.

Physiological characterization of Pseudomonas putida S1Pf1. Qualitative siderophore production was assayed on universal Chrome Azurol S (CAS) agar according to Schwyn et al. (42). Chitinase activity was assayed on the medium proposed by
Sridevi and Mallaiah (48) containing colloidal chitin prepared as described by Egger (13). The bacterial strain was inoculated at the center of the plate and incubated at $28^{\circ} \mathrm{C}$ for 5 and 10 days for siderophore synthesis and chitinase activity, respectively. Siderophore production was indicated by a color change from blue to orange on the CAS medium, while chitinase activity was revealed by the formation of a clearing halo around the colony on the medium containing colloidal chitin.

Both siderophore production and chitinase activity were measured in triplicate as the ratio between the two diameters of the halo and the two diameters of the colony.

IAA was quantified according to Forni et al. (17). The bacterial strain was inoculated in $20 \mathrm{ml}$ of M9 salt minimal medium added to sucrose $10 \mathrm{mM}$ and L-tryptophan $\left(400 \mathrm{mg} \mathrm{ml}^{-1}\right.$ ) (Fluka) and incubated on a rotary shaker at $150 \mathrm{rpm}$ in the dark at $28^{\circ} \mathrm{C}$ for 4 days. The bacterial suspension was centrifuged at $4,500 \mathrm{rpm}$ and $4{ }^{\circ} \mathrm{C}$ for $20 \mathrm{~min}$. Salkowsky's reagent $(2 \mathrm{ml})$ (38) was added to $1 \mathrm{ml}$ of the supernatant. After $30 \mathrm{~min}$ of incubation, the amount of IAA produced was evaluated at $\lambda 530 \mathrm{~nm}$ using an IAA solution $\left(100 \mathrm{mg} \mathrm{ml}^{-1}\right.$ ) as standard.

Acid phosphomonoesterase activity was measured as described by Eivazi and Tabatabai (14) and modified by Gamalero et al. (18) by measuring the amount of p-nitrophenol released by the substrate p-nitrophenylphosphate. Neutral and alkaline phosphomonoesterase activity was measured following Alef and Nannipieri (1) modified by Gamalero et al. (18) through the quantification of the phenol released by the enzymatic hydrolysis of the substrate disodium phenyl phosphate at $\mathrm{pH} 7$ and 10 , respectively.

The evaluation of ACC deaminase activity was performed by the method described by Li et al. (29). The bacterial strain was grown overnight in trypticase soy broth (TSB) (Fluka) at $28^{\circ} \mathrm{C}$ and the cells were harvested in the exponential phase. The pellet was washed in $0.85 \% \mathrm{NaCl}$, added in $1 / 10$ volume of DworkinFoster medium (12) containing $5 \mathrm{mM} \mathrm{ACC} \mathrm{(Sigma)} \mathrm{as} \mathrm{the} \mathrm{sole}$ nitrogen source, and incubated at $28^{\circ} \mathrm{C}$ for $6 \mathrm{~h}$. Then, the cells were harvested, washed, and resuspended in $0.1 \mathrm{M}$ Tris $\mathrm{HCl}$ $(\mathrm{pH}$ 8.5). The protein concentration for each crude extract was determined on toluenized cells (6). The ACC deaminase activity was quantified by measuring the amount of $\alpha$-ketobutyrate produced by the deamination of ACC. Then, $\approx 100 \mu \mathrm{g}$ of a protein extract in a $200-\mu \mathrm{l}$ volume was incubated with $50 \mathrm{mM} \mathrm{ACC}$ at $30^{\circ} \mathrm{C}$ for $20 \mathrm{~min}$. As negative controls, (i) buffer without the protein extract and (ii) the same amount of protein extract without additional ACC were considered. One unit of ACC deaminase activity indicated the formation of $1 \mathrm{nmol} \alpha$-ketobutyrate per milligram of protein per hour under these conditions.

Detection of salicylic acid (SA) was obtained following the method described by Leeman et al. (27). Three colonies of the bacterial strain were inoculated in $10 \mathrm{ml}$ of succinate standard medium (SSM) (34) and grown for $48 \mathrm{~h}$ at $28^{\circ} \mathrm{C}$ and $150 \mathrm{rpm}$. Washed cells were resuspended in $20 \mathrm{ml}$ of SSM added or not with $30 \mu \mathrm{M} \mathrm{FeCl}{ }_{3} 6 \mathrm{H}_{2} \mathrm{O}$ (Fluka) and grown for $48 \mathrm{~h}$ at $28^{\circ} \mathrm{C}$. After centrifugation at 5,000 rpm for $15 \mathrm{~min}$, the supernatant was filtered through a $0.2-\mu \mathrm{m}$ filter. For qualitative detection, $4 \mathrm{ml}$ of the supernatant was acidified to $\mathrm{pH} 2$ and extracted twice with $2 \mathrm{ml}$ of $\mathrm{CHCl}_{3}$ (Fluka); then, the absorbance spectrum of the organic phase was analyzed at 220 to $450 \mathrm{~nm}$ with 5-nm intervals. For SA quantification, $5 \mu \mathrm{l}$ of $2 \mathrm{M} \mathrm{FeCl}_{3}$ and $4 \mathrm{ml}$ of sterile demineralized water were added to the $\mathrm{CHCl}_{3}$ phase (35). The absorbance of the purple iron-SA complex was measured at $\lambda 527$ $\mathrm{nm}$ and compared with a standard curve (0 to $0.1 \mathrm{mg}$ SA per milliliter of SSM).

Negative controls were represented by the substrate blank. These physiological activities were also assayed on the rifampicin-resistant strain S1Pf1Rif.

Seed sterilization, plant growth conditions, and treatments. C. carinatum seed were surface sterilized by gently shaking in a 
$5 \%$ sodium hypochlorite solution for $3 \mathrm{~min}$. The seed were rinsed six times for $5 \mathrm{~min}$ and four times for $20 \mathrm{~min}$ in sterile deionized water, placed in petri dishes on moist sterile filter paper, and incubated in the dark at $24^{\circ} \mathrm{C}$ for 3 days. Twenty daisy seeds were placed on nutrient agar (NA) (Fluka) for 3 days in order to verify the efficacy of the sterilization procedure.

Daisy plants were grown in 8 -by-8-cm pots containing a mixture of 0.6 to $1.2 \mathrm{~mm}$ of coarse-grade quartz sand (Punto Elle, Turin, Italy) sterilized at $200^{\circ} \mathrm{C}$ for $2 \mathrm{~h}$. Plants were grown in a greenhouse $\left(25\right.$ to $20^{\circ} \mathrm{C}$, photoperiod of $16 \mathrm{~h}$ of light and $8 \mathrm{~h}$ of darkness) and watered to saturation three times per week with modified Long Ashton nutrient solution (50).

Bacterial inoculants were produced by growing the strain $\mathrm{S} 1 \mathrm{Pf} 1 \mathrm{Rif}$ on $\mathrm{KB}$ medium added to rifampicin at $28^{\circ} \mathrm{C}$ for $36 \mathrm{~h}$. Bacteria were pelleted by centrifugation $(4,500 \times g, 20 \mathrm{~min})$, washed twice, and suspended in $0.1 \mathrm{M} \mathrm{MgSO}_{4}$ and the density of the suspension was adjusted to $10^{10} \mathrm{CFU} \mathrm{m}{ }^{-1}$. Fifteen days after sowing, $5 \mathrm{ml}$ of this suspension was added to each pot in order to reach the final density of $10^{8} \mathrm{CFU} \mathrm{\textrm {g } ^ { - 1 }}$ of sand. Control plants were treated with $5 \mathrm{ml}$ of $0.1 \mathrm{M} \mathrm{MgSO}_{4}$.

Four treatments and 10 to 15 replicates per treatment were considered: control plants (C), CYP-infected plants (CY), Pseudomonas putida S1Pf1Rif-inoculated plants (S1Pf1Rif), and $P$. putida S1Pf1Rif-inoculated and CYP-infected plants (S1Pf1Rif+CY). The experiment was repeated four times (experiment repeats 1 to 4; in total, 52 plants per treatment were used) and the results presented here are the mean value of the data obtained by these independent experiments.

Phytoplasma and vector insect. The ' $\mathrm{Ca}$. Phytoplasma asteris' strain CYP, originally isolated from Argyranthemum frutescens (L.) Schultz-Bip plants in Liguria (Italy) (9), was maintained on daisy by vector transmission. Healthy colonies of $M$. quadripunctulatus were reared on potted oat plants inside plexiglas and nylon cages in growth chambers at 25 to $20^{\circ} \mathrm{C}$ with a photoperiod of $16 \mathrm{~h}$ of light and $8 \mathrm{~h}$ of darkness and checked by PCR assays to verify phytoplasma absence.

For transmission experiments, third-fifth instar nymphs were fed for 1 week on CYP-infected plants, transferred onto healthy oat for 2 weeks to complete latency, and then transferred singly to 10 to 15 daisy plants for an inoculation access period (IAP) of 3 days inside glass cylinders. Inoculation with single vectors was performed in order to assure a low initial concentration of the phytoplasmas in the plant. Test plants were exposed to vectors 2 months after sowing. The plants were then treated with insecticides and maintained in the greenhouse for 1 month. Daisy plants exposed to vectors were used as transmission controls and plants inoculated with $P$. putida S1Pf1Rif not exposed to vectors were used as treatment controls.

Symptom evaluation. Presence and severity of CYP symptoms on the plants were evaluated three times a week starting from their first appearance until 30 days postinoculation (dpi) and plants were classified into five classes of severity: $0=$ no symptoms, 1 = yellowing of the apex, 2 = yellowing and distortion of the apex, 3 = apex growth stunt, $4=$ severe yellowing and dwarfing of the whole plant, and $5=$ plant death.

Evaluation of plant development and root architecture. Ten plants per treatment were collected 3 months after sowing (at $30 \mathrm{dpi}$ ) and the following parameters determined: root and shoot fresh weight, shoot branching (measured as ratio of the number of leaves to the shoot), number of tips, total root length, mean root diameter, and degree of root branching (represented by root tip number divided by total root length). For this purpose, whole root systems were put in a water-transparent container and digitized using a dedicated Desk Scan II scanner, equipped with a special lighting system for root measurement. Digitized root images were analyzed by WinRhizo software (Régent Instruments, Canada).

Bacterial density. Bacterial density was assessed 10 weeks after sowing (at $30 \mathrm{dpi}$ ). Whole root systems were aseptically cut from five plants and gently washed with sterile water. Roots were then vortexed for $15 \mathrm{~min}$ in $\mathrm{MgSO}_{4}$ buffer $(0.1 \mathrm{M})$ and the suspensions were serially diluted and plated on solid $\mathrm{KB}$ supplemented with rifampicin $\left(100 \mu \mathrm{g} \mathrm{ml}^{\circ}\right)$. After incubation for $48 \mathrm{~h}$ at $25^{\circ} \mathrm{C}$, the numbers of $\mathrm{CFU}$ were determined and expressed per gram of root fresh weight.

Phytoplasma concentration: DNA extraction and quantitative real-time PCR. Samples of $200 \mathrm{mg}$ were collected from apical leaves of 5 plants per treatment at 17 and 24 dpi and total DNA was extracted from $100 \mathrm{mg}$ with the PureLink Plant Total DNA Purification Kit (Invitrogen, Carlsbad, CA) according to the manufacturer's protocol. The same plants were sampled at both dates and quantification was repeated three times. Concentration of DNA extracts was measured with a NanoDrop 1000 Spectrophotometer (Thermo Fisher Scientific, Wilmington, DE). Diluted samples ( $1 \mathrm{ng} / \mu \mathrm{l}$ in sterile double-distilled water) were analyzed in triplicate in quantitative real-time PCR (Q-PCR) assays. CYP DNA in each sample was measured as the number of CYP genome units (GU) per nanograms of plant DNA, as described by Marzachi and Bosco (32). Q-PCR reactions were performed with Platinum Quantitative Supermix-UDG (Invitrogen) with $300 \mathrm{nM}$ primers (CYS2Fw/Rv for CYP and ChrysFw/ $\mathrm{Rv}$ for daisy) and $200 \mathrm{nM}$ probes (CYS2Probe for CYP and ChrysProbe for daisy), together with $5 \mu$ l of the corresponding template, in a final volume of $25 \mu \mathrm{l}$. Reactions were run in 96well plates in a Bio-Rad iCycler (Bio-Rad, Hercules, CA) using cycling conditions described by Marzachi and Bosco (32). DNA from healthy plants and PCR mix devoid of template were used as negative controls. Threshold cycles and standard curves were automatically calculated by the Bio-Rad iCycler software, version 3.06070. CYP and host DNA from the same sample were quantified in the same plate.

Quantification of CY DNA was performed on plants from experiment repeats 2,3 , and 4 .

Phytoplasma viability: total RNA extraction and quantitative reverse-transcription real-time PCR. Total RNA was extracted with the Trizol Reagent (Invitrogen) following the manufacturer's recommendations from the remaining $100 \mathrm{mg}$ of daisy apical leaves ground to powder under liquid nitrogen. DNA contamination was removed by RQI RNase-free DNase (Promega, Milan, Italy) digestion at $37^{\circ} \mathrm{C}$ for $30 \mathrm{~min}$. Total RNA, extracted twice with a mixture of phenol and chloroform and precipitated with ethanol and ammonium acetate $(0.5 \mathrm{M})$, was then resuspended to a final concentration of $5 \mathrm{ng} / \mu \mathrm{l}$, and $1 \mu \mathrm{l}$ was loaded as template in quantitative reverse-transcription (Q-RT)PCR experiments. For the construction of the standard curve, the partial CYP-specific 16Sr DNA gene was amplified from plasmid pOP74 with primer pairs $\mathrm{R} 16 \mathrm{~F} 2 / \mathrm{R} 2$ as detailed in the original article (32). The amplicon ( $\approx 1,200 \mathrm{bp}$ ) was cloned into pGEM-T (Promega, Milan, Italy) vector and transformed into DH5 $\alpha$ (Invitrogen, UK) competent cells, following a routine protocol. Plasmid DNA, obtained with the Qiagen Plasmid Midi Kit (Qiagen, Italy), was linearized with PstI (Invitrogen) restriction enzyme $(10 \mathrm{U})$ for $2 \mathrm{~h}$ at $37^{\circ} \mathrm{C}$ and precipitated in the presence of sodium acetate and ethanol. Linearized plasmid DNA ( $1 \mu \mathrm{g})$ was transcribed in $20 \mu \mathrm{l}$ of reaction mix at $37^{\circ} \mathrm{C}$ for $1 \mathrm{~h}$ with T7 RNA polymerase (Maxi Script SP6/T7 kit; Applied Biosystems, Foster City, CA) following the kit's recommendations. DNA contamination was removed by DNase turbo (Ambion, Foster City, CA) digestion $(2 \mathrm{U})$ at $37^{\circ} \mathrm{C}$ for $30 \mathrm{~min}$. Total RNA, extracted twice with a mixture of phenol and chloroform and precipitated with ethanol and ammonium acetate $(0.5 \mathrm{M})$, was then resuspended in $20 \mu \mathrm{l}$ of diethylpyrocarbonate (DEPC)-treated water. The number of gene copies per nanogram of transcript was $1.56 \mathrm{E}+10^{9}$. Serial dilutions in DEPC-treated water $\left(1.0 \mathrm{E}+10^{9}, 1.0 \mathrm{E}+10^{8}\right.$, and $1.0 \mathrm{E}+10^{7}$ copy number/ $\left.\mu \mathrm{l}\right)$ were used as templates for the absolute quantification of the CYP $16 \mathrm{~S}$ rDNA transcripts in a one-step Q-RT-PCR method. For Q-RT-PCR, $1 \mu$ of RNA (5 ng) was 
added to $25 \mu$ l of reaction mix containing $2 \times$ Platinum Quantitative Supermix-UDG (Invitrogen), $300 \mathrm{nM}$ each forward and reverse primer (CYS2Fw/Rv), $200 \mathrm{nM}$ probes (CYS2Probe for CYP) (32), $50 \mathrm{U}$ of MuLV reverse transcriptase, and $10 \mathrm{U}$ of RNase Inhibitor (both from Applied Biosystems). RNA samples not supplemented with reverse transcriptase were used to rule out DNA contamination, while RNA from healthy plants and PCR mix devoid of template were used as negative controls. The Q-RTPCR samples were amplified in triplicate in 96-well plates in a Bio-Rad iCycler (Bio-Rad) and the cycle parameters were as follows: $52^{\circ} \mathrm{C}$ for $30 \mathrm{~min}, 95^{\circ} \mathrm{C}$ for $5 \mathrm{~min}, 95^{\circ} \mathrm{C}$ for $15 \mathrm{~s}$, and $60^{\circ} \mathrm{C}$ for $1 \mathrm{~min}$ ( 45 cycles). Number of phytoplasma $16 \mathrm{~S}$ transcripts per nanogram of total RNA of each sample was determined. Number of phytoplasma transcripts per $100 \mathrm{mg}$ of fresh leaf tissue was then derived. The viability of CYP (expressed as number of $16 \mathrm{~S}$ transcripts per phytoplasma cell) was calculated by dividing the transcript copy number by the number of CYP cells measured in $100 \mathrm{mg}$ of the same sample (as detailed above).

Quantification of CY RNA was performed on plants from experiment repeats 3 and 4 .

Microscopic observations. Fully developed leaves of plants belonging to the four treatments were considered for microscopic analysis. At plant harvest, the apical and basal zones of each leaf were separated, fixed overnight in $3 \%$ glutaraldehyde in $0.15 \mathrm{M}$ phosphate buffer ( $\mathrm{pH} 7.2$ at $4^{\circ} \mathrm{C}$ ), post-fixed for 150 min with $1 \%$ osmium tetroxide in the same buffer, dehydrated in ethanol series (30 to 100\%), and embedded in Epon-Araldite resin. The tissues were stained with uranyl acetate during the dehydration step. Ultrathin sections, cut with a diamond knife in a Leica Ultracut UCT ultramicrotome (Milan, Italy), were stained with lead citrate and observed through a Philips CM 10 (Eindhoven, Netherland), electron microscope. Ten leaves for each plant treatment were sampled and their relative sections were observed.

Statistical analysis. Because bacterial populations approximate an exponential normal distribution, bacterial density values were logarithmically transformed before analysis. Data on plant growth and root architecture obtained from 10 plants/treatment were expressed as mean values. Nontransformed and transformed values were submitted to analysis of variance (ANOVA) and to Fisher's least significant test $(P \leq 0.05)$ using the Statview 5.0 statistics package (SAS Institute Inc., Cary, NC).

To analyze symptom development in control and elicited plants, the median number of days required by each plant to reach each symptom severity class was calculated and then compared with the nonparametric Mann-Whitney $U$ Test using SigmaPlot 11 (Systat Software Inc., San José, CA).

For the analyses of phytoplasma concentration, raw data (obtained as $\log$ ) were used and the concentration of CYP in each plant was expressed as the difference between the logarithm concentration of CYP and that of daisy DNAs. To compare the phytoplasma titer measured at different dpi in elicited and control plants, two-way ANOVA for treatment and date was performed (SigmaPlot 11.0, Systat Software, Inc., San Jose, CA).
For the analyses of phytoplasma viability, raw data (CYP transcripts/CYP cells) were transformed into logarithms, because the standard deviation appeared a function of the mean. To compare the number of $16 \mathrm{~S}$ rDNA transcripts per CY cell (as an estimator of phytoplasma viability) at different dpi in elicited and control plants, two-way ANOVA for treatment and date was performed.

\section{RESULTS}

Identification and physiological traits of the bacterial strain. A comparison of the 16s rRNA gene sequence of the strain S1Pf1 with the GenBank collection of sequences was performed using BLAST. Strain S1Pf1 was identified as $P$. putida with an identity of $99 \%$. The bacterial strain showed plant beneficial activities such as the ability to solubilize phosphate and to produce siderophores and the phytohormon IAA (Table 1). $P$. putida S1Pf1 was unable to synthesize SA or the enzyme ACC deaminase and to produce chitinase (Table 1).

Effect of CY and $P$. putida S1Pf1Rif on plant growth and root architecture. Plant growth was significantly reduced by CYP. The plant fresh weight in CY-infected plants was $37.3 \%$ lower than that of the control (Fig. 1A) $(P=0.0011)$. P. putida S1Pf1Rif did not affect plant growth (Fig. 1A to C) but neutralized plant growth depression observed in CY-infected plants (Fig. 1A) $(P=0.0176)$. In particular, root and shoot fresh weight in CYP-infected plants were reduced by 39.4 and $34.8 \%$, respectively, compared with controls (Fig. 1B and C) $(P=0.0074$ and 0.0065). Nevertheless, the shoot fresh weight of plants inoculated with the strain S1Pf1Rif and infected by CYP was significantly higher $(P=0.0171)$ than that of CYP-infected plants $(+49.7 \%)$ (Fig. 1C). In contrast, inoculation with the strain S1Pf1Rif did not alleviate the CYP-induced reduction of root fresh weight. The number of leaves per shoot length (shoot branching) in CYP-infected plants was significantly increased compared with control plants $(+69.7 \%, P=0.0127)$ (Fig. 1D). However, in plants inoculated with strain S1Pf1Rif and infected by CYP, the shoot branching degree was similar to that of control plants (Fig. 1D).

$P$. putida S1Pf1Rif slightly reduced $(-21 \%, P=0.0065)$ the number of tips while CYP significantly reduced the number of tips $(-58.1 \%, P<0.0001)$, total root length $(-44 \%, P=0.003)$, and root branching $(-28.6 \%, P=0.0049)$ (Table 2). Bacterial inoculation did not rescue this root modification (Table 2). Mean root diameter was similar in all of the plant treatments (Table 2).

Symptom evaluation. Symptom development was followed for all of the plants every 3 days for a period of 30 days starting from the ninth day after CYP inoculation. Control plants and those inoculated with S1Pf1Rif did not develop any symptoms (data not shown). Following inoculation with CYP-infective leafhoppers, 8 of the 52 plants inoculated with $P$. putida S1Pf1Rif and 5 of the 52 CYP-infected plants never developed phytoplasma-specific symptoms $\left(\chi^{2}=0.352 ; P=0.553\right)$. Results from the different

TABLE 1. Qualitative and quantitative analysis of functional traits of Pseudomonas putida S1Pf1

\begin{tabular}{|c|c|c|}
\hline Functional traits & Ratio $^{z}$ & Units measured \\
\hline \multicolumn{3}{|l|}{ Qualitative analysis } \\
\hline Siderophore & $5.5 \pm 0.2$ & $\ldots$ \\
\hline Chitinase & $0.0 \pm 0.0$ & $\ldots$ \\
\hline \multicolumn{3}{|l|}{ Quantitative analysis } \\
\hline Alkaline phosphomonoesterase & $\ldots$ & Phenol at $3,431.1 \pm 27.5 \mu \mathrm{g} \mathrm{ml}^{-1} \mathrm{~h}^{-1}$ \\
\hline Neutral phosphomonoesterase & $\ldots$ & Phenol at $199.3 \pm 4.6 \mu \mathrm{g} \mathrm{ml}^{-1} \mathrm{~h}^{-1}$ \\
\hline Acid phosphomonoesterase & $\ldots$ & p-Nitrophenol at $991.8 \pm 15.7 \mu \mathrm{g} \mathrm{ml}^{-1} \mathrm{~h}^{-1}$ \\
\hline Indole acetic acid (IAA) & $\ldots$ & IAA at $10.6 \pm 0.6 \mu \mathrm{g} \mathrm{m}^{-1} \mathrm{~h}^{-1}$ \\
\hline Salicylic acid (SA) & $\ldots$ & SA at $0.0 \pm 0.0 \mu \mathrm{g} \mathrm{ml}^{-1}$ \\
\hline 1-Aminocyclopropane-1-carboxylate deaminase & $\ldots$ & $0.0 \pm 0.0 \mathrm{nmol} \alpha$-ketobutyrate $/ \mathrm{mg}$ of protein $/ \mathrm{h}$ \\
\hline
\end{tabular}

${ }^{\mathrm{z}}$ Mean value of the ratio between the diameters of the halo and the diameters of the colony. 

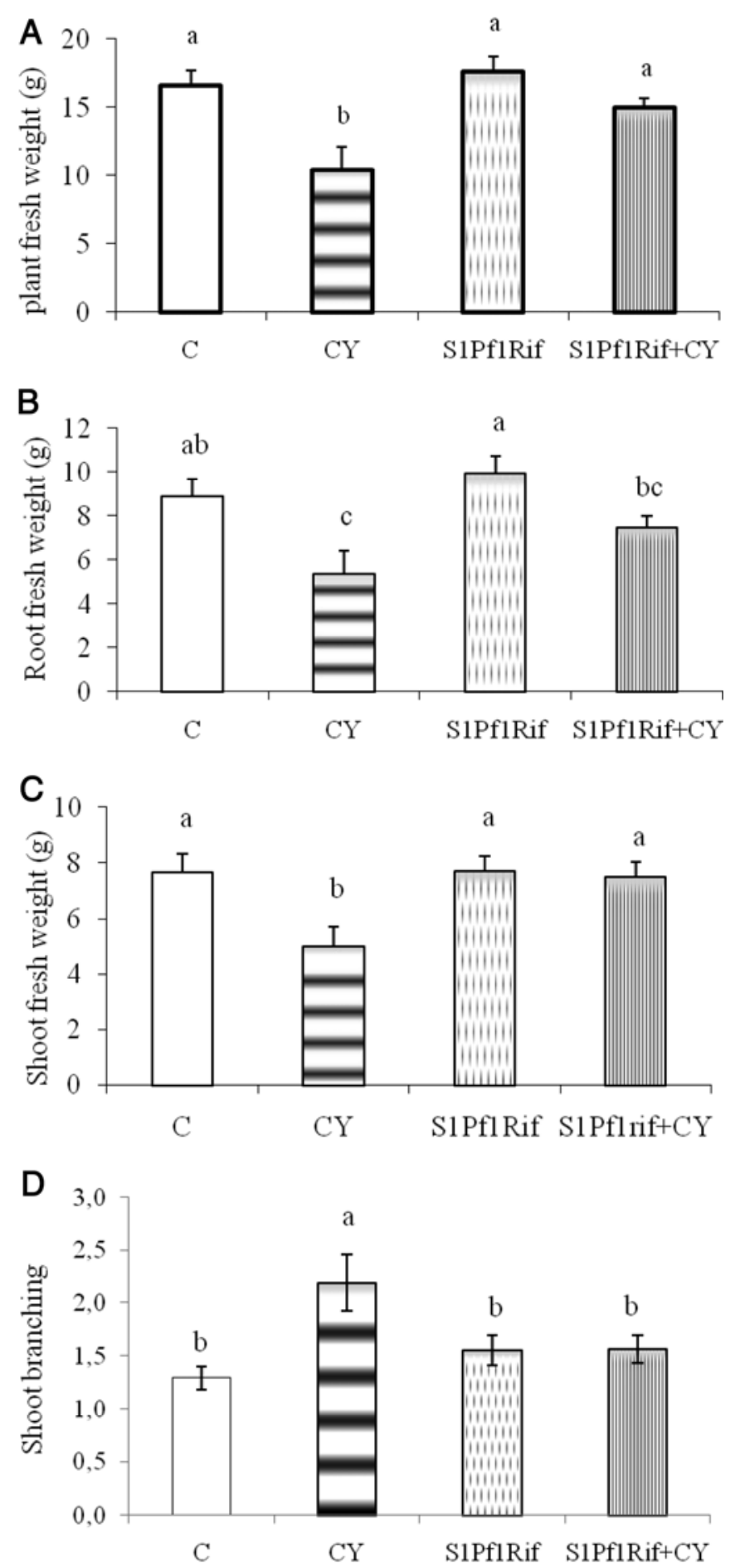

Fig. 1. A, Plant; B, root; C, shoot fresh weight; and $\mathbf{D}$, shoot branching of control (C) plants and plants infected by chrysanthemum yellows (CY), inoculated with Pseudomonas putida S1Pf1Rif, or both (S1Pf1Rif+CY). Means designated with the same letter are not significantly different $(P \leq$ 0.05 ) according to Fisher's least significant difference test. experiments (repeats) were pooled for the analysis because a oneway ANOVA on ranks did not reveal differences among repeats for both control and inoculated plants. Median number of days required to reach the different symptom severity classes were very similar and no significant differences were found between these treatments (Table 3).

Bacterial density. Bacterial density was evaluated at the harvest of the plants and measured as $\log \mathrm{CFU} / \mathrm{g}$ of root fresh weight. No significant differences were detected between plants inoculated with the bacterial strain $(3.74 \pm 0.15)$ and those also infected with CYP $(4.05 \pm 0.05)$.

CY titer and viability. Phytoplasma titer and viability in CYPinfected plants, inoculated or not with S1Pf1Rif, was evaluated on apical leaves at 17 and 24 dpi. Results from the three experiments were pooled for the analyses because a two-way ANOVA for treatment and repeat did not reveal differences among repeats (17 dpi, $P=0.990 ; 24 \mathrm{dpi}, P=0.772$ ). The same analysis did not reveal differences between treatments or interactions between treatments and repeats. CYP concentration increased significantly between 17 and 24 dpi $(P=0.022)$. Phytoplasma titer in CYPinfected plants inoculated or not with $P$. putida S1Pf1Rif were similar $(P=0.522)$. There was not a statistically significant interaction between date and treatment. Mean numbers of CYP cells in infected plants inoculated or not with S1Pf1Rif are shown in Table 4.

Phytoplasma activity, measured as the number of $16 \mathrm{~S}$ transcripts per CYP cell, was also evaluated on apical leaves at 17 and 24 dpi. Results from the two experiments were pooled for the analyses because a two-way ANOVA for treatment and repeat did not reveal differences among repeats $(17 \mathrm{dpi}, P=0.415 ; 24 \mathrm{dpi}$, $P=0.971)$. The same analysis did not reveal differences between treatments or interactions between treatments and repeats. The

TABLE 3. Chrysanthemum yellows phytoplasma (CYP) symptom severity for Pseudomonas putida S1Pf1Rif-elicited and control plants observed from 9 until 30 days post inoculation

\begin{tabular}{lccc}
\hline & \multicolumn{2}{c}{ Median $^{\mathrm{z}}$} & \\
\cline { 2 - 3 } Symptom class & $\mathrm{CY}$ & S1Pf1Rif $+\mathrm{CY}$ & Mann-Whitney test \\
\hline 1 & 12.00 & 12.00 & $\mathrm{U}=316.5, P=0.276$ \\
2 & 15.00 & 15.00 & $\mathrm{U}=220.5, P=0.106$ \\
3 & 19.5 & 21.0 & $\mathrm{U}=248.5, P=0.090$ \\
4 & 25.00 & 25.00 & $\mathrm{U}=239.0, P=0.952$ \\
\hline
\end{tabular}

${ }^{\mathrm{z}}$ Median number of days required to reach a certain disease severity class.

TABLE 4. Chrysanthemum yellows phytoplasma (CYP) concentration in Pseudomonas putida S1Pf1Rif-inoculated and control daisy plants expressed as the mean of CYP cells/ng of plant \pm standard error (se) of each plant sampled at 17 and 24 days post inoculation $(\mathrm{dpi})^{\mathrm{z}}$

\begin{tabular}{lcc}
\hline & \multicolumn{2}{c}{ Mean genome units/ng of plant DNA (se) } \\
\cline { 2 - 3 } Sample (dpi) & CY & S1Pf1Rif+CY \\
\hline 17 & $146,500(3,030) \mathrm{a}$ & $149,000(2,950) \mathrm{a}$ \\
24 & $324,000(6,050) \mathrm{b}$ & $272,000(5,080) \mathrm{b}$ \\
\hline
\end{tabular}

${ }^{\mathrm{z}}$ Within rows and columns, means followed by the same letter do not differ significantly.

TABLE 2. Number of tips (T), total root length (TL), mean root diameter (D), and root branching degree (T/TL) in daisy plants inoculated or not with Pseudomonas putida S1Pf1Rif and infected or not with chrysanthemum yellows phytoplasma (CYP) ${ }^{\mathrm{z}}$

\begin{tabular}{lllll}
\hline & \multicolumn{1}{c}{ T } & \multicolumn{1}{c}{ TL $(\mathrm{cm})$} & $\mathrm{D}(\mathrm{mm})$ & $\mathrm{T} / \mathrm{TL}$ \\
\hline Control & $5,974.8 \pm 397.8 \mathrm{a}$ & $4,414.7 \pm 348.9 \mathrm{a}$ & $0.4 \pm 0.0 \mathrm{a}$ & $1.4 \pm 0.1 \mathrm{a}$ \\
CY & $2,503.0 \pm 186.3 \mathrm{c}$ & $2,472.9 \pm 96.9 \mathrm{~b}$ & $0.4 \pm 0.0 \mathrm{a}$ & $1.0 \pm 0.0 \mathrm{~b}$ \\
S1Pf1Rif & $4,674.6 \pm 546.6 \mathrm{~b}$ & $4,085.3 \pm 351.2 \mathrm{a}$ & $0.4 \pm 0.0 \mathrm{a}$ & $1.1 \pm 0.1 \mathrm{ab}$ \\
S1Pf1Rif+CY & $2,535.0 \pm 216.9 \mathrm{c}$ & $2,797.4 \pm 257.8 \mathrm{~b}$ & $0.4 \pm 0.0 \mathrm{a}$ & $0.9 \pm 0.0 \mathrm{~b}$ \\
\hline
\end{tabular}

$\mathrm{z}$ Values are means of five plants \pm standard error. Within columns, means designated with the same letter are not significantly different $(P \leq 0.05)$ according to Fisher's least significant difference test. 
phytoplasma activity decreased significantly over time $(P<$ $0.001)$ but was similar in CYP-infected plants inoculated or not with S1Pf1Rif $(P=0.291)$ (Table 5). There was not a statistically significant interaction between date and treatment.

TABLE 5. Number of chrysanthemum yellows (CY) 16SrDNA transcripts per phytoplasma cell estimated in $100 \mathrm{mg}$ of fresh leaf tissues of Pseudomonas putida S1Pf1Rif-treated and control plants sampled at 17 and 24 days postinoculation (dpi) ${ }^{\mathrm{z}}$

\begin{tabular}{lll}
\hline & \multicolumn{2}{c}{ Mean CY 16S rDNA transcripts/CY cell (standard error) } \\
\cline { 2 - 3 } Sample (dpi) & CYP control & S1Pf1Rif+CYP \\
\hline 17 & $4,455(946) \mathrm{a}$ & $6,754(1,418) \mathrm{a}$ \\
24 & $1,207(349) \mathrm{b}$ & $1,257(208) \mathrm{b}$ \\
\hline
\end{tabular}

${ }^{\mathrm{z}}$ Within rows and columns, means followed by the same letter do not differ significantly.
Microscopic observations. No phytoplasma cells were detected in uninfected control plants and $P$. putida S1Pf1Rifinoculated ones. In contrast, phytoplasmas were found in the phloem of all the organs of CY-infected plants observed, including fully developed leaves. In the leaf apical zone of CYPinfected plants, phytoplasmas showed different sizes and dense cytoplasm, whereas senescent phytoplasma cells were rarely detected (Fig. 2A). The entire lumen of the phloematic vessel in the leaf basal zone of CYP-infected plants was often filled with phytoplasma cells with different shapes and sizes and at different stage of development (Fig. 2B). In fully developed leaves of CYP-infected plants inoculated with $P$. putida S1Pf1Rif, phytoplasmas were differently spread and showed a different morphology. In the leaf apical zone of CYP-infected daisy plants inoculated with S1Pf1Rif, phytoplasmas often showed features of degeneration, such as cytoplasm confined at the periphery of the
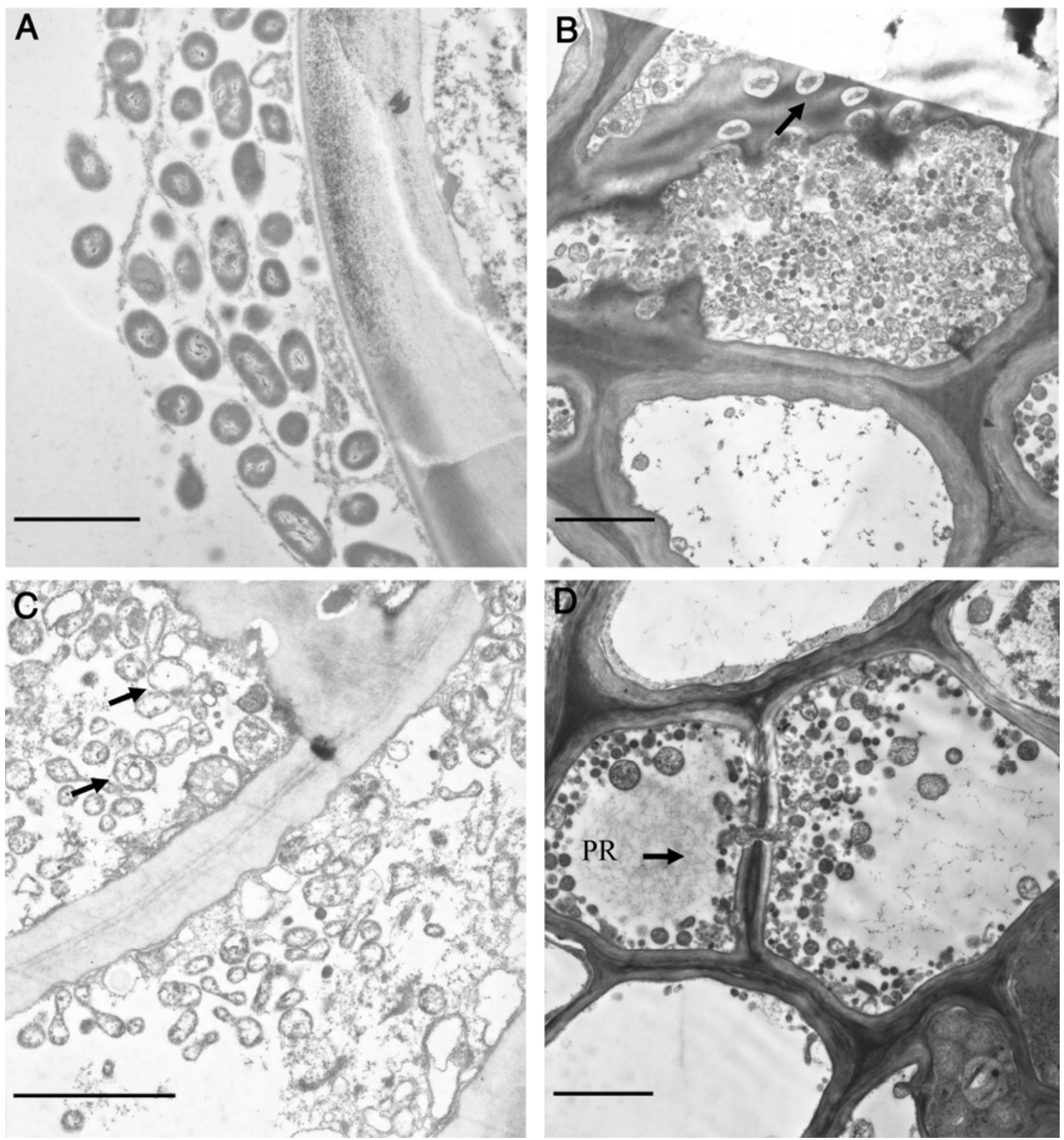

Fig. 2. Transmission electron micrographs of fully differentiated lateral leaves. A, Leaf apical zone of chrysanthemum yellows phytoplasma (CYP)-infected plants. Differently sized phytoplasma cells with dense cytoplasm are evident (magnification $\times 8,900)$. B, Leaf basal zone of CYP-infected plants. Phloematic vessel are filled with phytoplasma cells. The arrow indicates callose deposition on the sieve pore, while the black one cell wall distortion (magnification $\times 7,000)$. $\mathbf{C}$, Leaf apical zone of CYP-infected plants inoculated with Pseudomonas putida S1Pf1Rif. Phytoplasma cells are often degenerated; constrained DNA and cytoplasm confined closed to the cell wall are indicated by arrows (magnification $\times 11,500)$. D, Leaf basal zone of CYP-infected plants inoculated with $P$. putida S1Pf1Rif. Phytoplasma cells showed different developmental stages. The arrow indicates the movement of phytoplasma through the sieve elements (magnification $\times 7,000$ ). $\mathrm{PR}=$ pathogenesis-related proteins. Bars in the figures represent $20 \mu \mathrm{m}$. 
phytoplasma cells (Fig. 2C). Degenerated phytoplasmas, together with cells having normal shape, sometimes moving across the sieve pore of the phloematic vessel, were observed in the basal zone of the leaves of CYP-infected plants inoculated with S1Pf1Rif (Fig. 2D).

A high number of degenerated phytoplasmas was constantly found in infected plants inoculated with the strain S1Pf1Rif. The host cells often showed symptoms not observed in the healthy controls, such as distorted cell walls (Fig. 2B), deposition of callose near the sieve pores (Fig. 2B), and synthesis of pathogenesis-related (PR) proteins (Fig. 2D).

\section{DISCUSSION}

The application of plant-beneficial bacteria to control phytoplasma disease has never been explored. In this work, the activity of a plant-beneficial bacterial strain on CY infection of daisy was characterized by measuring plant growth (evaluated as plant biomass and root development), symptom severity, and phytoplasma multiplication and viability inside the host plant. $P$. putida S1Pf1Rif was isolated from the soil next to a symptomless grapevine plant growing in a vineyard where grapevine yellows diseases were spread. This strain was chosen for its peculiar origin and for its potential plant-beneficial physiological activities such as the production of IAA and siderophores and the synthesis of phosphomonoesterases.

Phytoplasmas negatively impacted the fitness and health of their plant hosts, inducing a wide range of symptoms. The detrimental effect of CYP on daisy development was manifest on both the shoot and root system, as previously reported for other herbaceous phytoplasma-infected plants $(15,26,30)$. CYP also induced a significant increase of the number of leaves per centimeter of shoot length, leading to the typical phytoplasma symptom known as witches' broom. In contrast with what was observed in the pathosystem of Stolbur phytoplasma-Lycopersicum esculentum Mill. (30), CYP infection reduced the tip number, total root length, and root branching degree, leading to a less-developed and less-efficient root system $(2,25)$. Because the total root length of the infected plants was significantly reduced, the total soil volume explored was expected to be lower than that explored by the root system of healthy plants. This difference would account for the reduced growth of the diseased plants as measured by the plant weight.

$P$. putida S1Pf1Rif did not affect daisy growth; therefore, a direct plant growth promotion activity on this plant species can be excluded. However, this bacterial strain neutralized the deleterious impact of CYP on the weight of the aerial part of daisy. In contrast, no beneficial relief by the strain S1Pf1Rif on CYPinfected daisy was observed at the root level. Actually, in this organ, CYP titer is higher compared with that of leaves (39), probably due to a more active multiplication in root tissues or translocation of the pathogen to roots following the phloem stream after multiplication in other plant organs. This can explain the inability of S1Pf1Rif to relieve phytoplasma damage at the root level. Phytoplasma titer inside the host was not affected by $P$. putida S1Pf1Rif. Therefore, we decided to assess possible variation of phytoplasma viability in the plant. $16 \mathrm{~S}$ rRNA is considered to be one of the targets to measure metabolic activity of bacterial populations (40). Here, a robust and precise method for the quantification of the phytoplasma 16S rRNA transcripts per phytoplasma cell based on a Q-RT-PCR analysis was developed. Although Q-RT-PCR on rRNA has been used to quantify viability of bacterial strains in pure culture $(16,51)$, to our knowledge, this is the first application of this technique to measure viability of an unculturable obligate parasite inside its host. The metabolic activity was expressed as the ratio between the number of ribosomal transcripts present in $100 \mathrm{mg}$ of fresh leaf tissue and the number of phytoplasma cells in the same sample. For this purpose, RNA standards were developed for QRT-PCR analysis. CYP viability in both P. putida-inoculated and control plants decreased over time, with the aging of the plant and the worsening of the symptoms. Although a certain amount of cellular rRNA is present in starving bacterial populations $(41,46)$, a decline in bacterial ribosomal content precedes the decline in protein synthesis in Escherichia coli (51). This result suggests that, regardless of the presence of the strain S1Pf1Rif, CYPinfected plants loose the capability to fully support phytoplasma metabolic activity with time. This hypothesis is consistent with the alteration of photosynthate transport efficiency in phloematic vessels, due to callose deposition on the sieve elements, observed through electron microscopy in CYP-infected plants. Moreover, microscopic observations allowed us to detect differences in phytoplasma abundance and morphology, according to the plant treatment and leaf zone. In general, phytoplasma cells were present in both the apical and basal zones of lateral leaves. However, in CYP-infected plants inoculated with S1Pf1Rif, the phytoplasma morphology (empty cells and cells with cytoplasm confined at the periphery) was typical of senescent cells, clearly indicating the occurrence of a degenerative process, especially in the apical zone of the lateral leaves. The deposition of callose in the pore of the sieve element and the synthesis of PR protein in the host plant indicate that defense mechanisms were active in CYP-infected plants. Although viable phytoplasmas in young apical leaves of infected plants inoculated with S1Pf1Rif were detected by molecular analysis, CYP cells in lateral, fully differentiated leaves observed by TEM did not show the typical morphology of viable cells. These data, together with the presence of viable phytoplasmas in both young apical and fully developed lateral leaves of CYP-infected plants, indicate an increase of plant tolerance against the pathogen in the plants treated with the pseudomonad.

Overall, these results indicate that S1Pf1Rif induces a relief of phytoplasma damages to the aerial part of the plant but has no direct effect on phytoplasmas that are present and viable inside the plant.

Therefore, it is likely that $P$. putida S1Pf1Rif acts to improve the tolerance of the plant to CYP infection rather than directly on the phytoplasma cell. This tolerance cannot be ascribed to a reduced stress ethylene level by ACC deaminase activity or to the induction of systemic resistance though SA synthesis. However, siderophores produced by the fluorescent pseudomonads may be involved in both antagonism against phytopathogens $(7,28)$ and ISR elicitation $(27,33,52)$. In our experimental setup, iron is provided to the model plant as a micronutrient three times a week; therefore, the synthesis of bacterial siderophores mediating iron competition or triggering ISR may play only a minor or no role. The effect of other bacterial determinants able to elicit ISR (an iron-regulated $\mathrm{N}$-alkylated benzylamine derivative, the O-antigen of the lipopolysaccharides and the flagella) (33) cannot be ruled out.

In addition, the physiological characterization of the $P$. putida S1Pf1Rif performed in this study showed that this strain is able to produce IAA. It is well known that, according to the amount of IAA synthesized by soil bacteria, auxin triggers changes in plant gene regulation, resulting in a wide variety of effects, ranging from beneficial to damaging (47). Moreover, IAA and indole-3butyric acid are involved in recovery of phytoplasma-infected periwinkle (10). It has been recently shown that expression of a ' $\mathrm{Ca}$. Phytoplasma asteris' virulence factor (TENGU) in transgenic tobacco plants downregulates auxin signaling and biosynthesis pathway genes, resulting in altered plant growth (26). The reduced IAA endogenous levels in phytoplasma-infected plants could be partially relieved by the exogenous IAA provided by the pseudomonad. CYP concentration in roots is even higher than in apical leaves (39) and this can explain the failure of the pseudomonad in relieving CYP effects on roots. Alternatively, the 
concentration of bacterial IAA in roots, due to the rapid translocation of solutes through the phloem, may not be enough to rescue CYP effects on this organ.

Although the clear mechanism involved in symptom relief observed in CYP-infected plants inoculated with $P$. putida S1Pf1Rif has not been identified yet, to our knowledge this is the first article reporting a beneficial effect of a rhizospheric bacterium on plants infected with phytoplasma. The development of the new molecular methods aimed at quantifying not only the number of phytoplasma cells but also their viability inside the plants represents a further step to elucidate the pathogenic effect of phytoplasmas.

\section{ACKNOWLEDGMENTS}

This work has been supported by the Piedmont Region within the project "Valutazione dell'azione di microrganismi rizosferici ed elicitori di resistenza sull'infezione da fitoplasmi in un sistema modello (CIPE 2006)." We thank G. Lingua for critical reading of the manuscript and G. Bonelli for technical assistance in electron microscopy.

\section{LITERATURE CITED}

1. Alef, K., and Nannipieri, P. 1995. Pages 336-367 in: Methods in Applied Soil Microbiology and Biochemistry. Academic Press, London.

2. Berta, G., Fusconi, A., and Trotta, A. 1993. VA mycorrhizal infection and the morphology and function of root systems. Environ. Exp. Bot. 33:159173.

3. Berta, G., Sampò, S., Gamalero, E., Massa, N., and Lemanceau, P. 2005. Suppression of Rhizoctonia root-rot of tomato by Glomus mossae BEG12 and Pseudomonas fluorescens A6RI is associated with their effect on the pathogen growth and on the root morphogenesis. Eur. J. Plant Pathol. 111:279-288.

4. Bertaccini, A. 2007. Phytoplasmas: Diversity, taxonomy, and epidemiology. Front. Biosci. 12:673-689.

5. Bosco, D., Galetto, L., Leoncini, P., Saracco, P., Raccah, B., and Marzachi, C. 2007. Interrelationships between 'Candidatus Phytoplasma asteris' and its leafhopper vectors (Homoptera: Cicadellidae). J. Econ. Entomol. 100:1504-1511.

6. Bradford, M. M. 1976. A rapid and sensitive method for quantitation of microgram quantities of protein utilizing the principle of protein-dyebinding. Anal. Biochem. 72:248-254.

7. Buysens, S., Heungens, K., Poppe, J., and Höfte, M. 1996. Involvement of pyochelin and pyoverdine in suppression of Pythium-induced damping-off of tomato by Pseudomonas aeruginosa 7NSK2. Appl. Environ. Microbiol. 62:865.871

8. Chen, C., Bauske, E. M., Musson, G., Rodriguez-Kabana, R., and Kloepper, J. W. 1995. Biological control of Fusarium-wilt on cotton by use of endophytic bacteria. Biol. Control 5:83-91.

9. Conti, M., and Mela, L. 1987. Il giallume della margherita (Chrysanthemum frutescens), micoplasmosi tipica della riviera ligure. Dif. Piante 10:171-178.

10. Curković Perica, M. 2008. Auxin-treatment induces recovery of phytoplasma-infected periwinkle. J. Appl. Microbiol. 105:1826-1834.

11. D’Amelio, R., Massa, N., Gamalero, E., D'Agostino, G., Sampò, S., Berta, G., Faoro, F., Iriti, M., Bosco, D., and Marzachì, C. 2007. Preliminary results on the evaluation of the effects of elicitors of plant resistance on chrysanthemum yellows phytoplasma infection. Bull. Insectol. 60:317-318.

12. Dworkin, M., and Foster, J. W. 1958. Experiments with some microorganisms which utilize ethane and hydrogen. J. Bacteriol. 75:592595.

13. Egger, K. N. 1986. Substrate hydrolysis patterns of post-fire Ascomycetes (Pezizales). Mycologia 78:771-780.

14. Eivazi, F., and Tabatabai, M. A. 1977. Phosphatases in soils. Soil Biol. Biochem. 9:167-172.

15. Favali, M. A., Musetti, R., Benvenuti, S., Bianchi, A., and Pressacco, L. 2004. Catharanthus roseus L. plants and explants infected with phytoplasmas: alkaloid production and structural observations. Phytoplasma 223:45-51.

16. Fey, A., Eichler, S., Flavier, S., Christen, R., Hofle, M. G., and Guzman, C. A. 2004. Establishment of a real-time PCR-based approach for accurate quantification of bacterial RNA targets in water, using Salmonella as a model organism. Appl. Environ. Microbiol. 70:36183623.

17. Forni, C., Riov, J., Grilli-Caiola, M., and Tel-Or, E. 1992. Indole-3-acetic acid (IAA) production by Arthrobacter species isolated from Azolla. J. Gen. Microbiol. 138:377-381.

18. Gamalero, E., Fracchia, L., Cavaletto, M., Garbaye, J., Frey-Klett, P., Varese, G. C., and Martinotti, M. G. 2003. Characterization of functional traits of two fluorescent pseudomonads isolated from basidiomes of ectomycorrhizal fungi. Soil Biol. Biochem. 35:55-65.

19. Gamalero, E., Martinotti, M. G., Trotta, A., Lemanceau, P., and Berta, G. 2002. Morphogenetic modifications induced by Pseudomonas fluorescens A6RI and Glomus mosseae BEG12 in the root system of tomato differ according to plant growth conditions. New Phytol. 155:293-300.

20. Gamalero E., Trotta, A., Massa, N., Copetta, A., Martinotti, M. G., and Berta, G. 2004. Impact of two fluorescent pseudomonads and an arbuscular mycorrhizal fungus on tomato plant growth, root architecture and $P$ acquisition. Mycorrhiza 14:185-192.

21. Glick, B. R. 1995. The enhancement of plant growth by free-living bacteria. Can. J. Microbiol. 41:109-117.

22. Glick, B. R., Penrose, D. M., and Li, J. 1998. A model for the lowering of plant ethylene concentrations by plant growth-promoting bacteria. J. Theor. Biol. 190:63-68.

23. Gopal, M., Gupta, A., and Nair, R. V. 2005. Variations in hosting beneficial plant-associated microorganisms by root (wilt)-diseased and field-tolerant coconut palms of West Coast Tall variety. Curr. Sci. 89:1922-1927.

24. Gyaneshwar, P., Kumar, G. N., Parekh, L. J., and Poole, P. S. 2002. Role of soil microorganisms in improving $\mathrm{P}$ nutrition of plants. Plant Soil 245:83-93.

25. Hodge, A., Berta, G., Doussan, C., and Merchan, F. 2009. Plant root growth, architecture and function. Plant Soil 321:153-187.

26. Hoshi, A., Oshima, K., Kakizawa, S., Ishii, Y., Ozeki, J., Hashimoto, M., Komatsu, K., Kagiwada, S., Yamaji, Y., and Namba, S. 2009. A unique virulence factor for proliferation and dwarfism in plants identified from a phytopathogenic bacterium. Proc. Natl. Acad. Sci. USA 106:6416-6421.

27. Leeman, M., Vanpelt, J. A., Den Ouden, F. M., Heinsbroek, M., Bakker, P. A. H. M., and Schippers, B. 1996. Iron availability affects induction of systematic resistance to Fusarium wilt to radish by Pseudomonas fluorescens. Phytopathology 86:149-155.

28. Lemanceau P., Bakker, P. A. H. M., De Kogel, W. J., Alabouvette, C., and Schippers, B. 1992. Effect of pseudobactin 358 production by Pseudomonas putida WCS358 on suppression of Fusarium wilt of carnations by nonpathogenic Fusarium oxysporum Fo47. Appl. Environ. Microbiol. 58:2978-2982.

29. Li, J., Shah, S., Moffatt, B. A., and Glick, B. R. 2001. Isolation and characterization of an unusual 1-aminocyclopropane-1-carboxylic acid (ACC) deaminase gene from Enterobacter cloacae UW4. Antonie Leeuwenhoek 80:255-261.

30. Lingua, G., D’Agostino, G., Massa, N., Antosiano, M., and Berta, G. 2002. Mycorrhiza-induced differential response to a yellows disease in tomato. Mycorrhiza 12:191-198.

31. Mannini, F. 2007. Hot water treatment and field coverage of mother plant vineyards to prevent propagation material from phytoplasma infections. Bull. Insectol. 60:311-312.

32. Marzachì, C., and Bosco, D. 2005. Relative quantification of chrysanthemum yellows (16Sr I) phytoplasma in its plant and insect host using real time PCR. Mol. Biotechnol. 30:117-127.

33. Mercado-Blanco, J., and Bakker, P. A. H. M. 2007. Interactions between plants and beneficial Pseudomonas spp.: exploiting bacterial traits for crop protection. Antonie Leeuwenhoek 92:367-389.

34. Meyer, J. M., and Abdallah, M. A. 1978. The fluorescent pigment of Pseudomonas fluorescens: biosynthesis, purification and physicochemical properties. J. Gen. Microbiol. 107:319-328.

35. Meyer, J. M., Azelvandre, P., and Georges, C. 1993. Iron metabolism in Pseudomonas: salicylic acid, a siderophore of Pseudomonas fluoresecens CHA0. Biofactors 4:23-27.

36. Morone, C., Boveri, M., Giosuè, S., Gotta, P., Rossi, V., Scapin, I., and Marzachì, C. 2007. Epidemiology of flavescence dorée in vineyards in northwestern Italy. Phytopathology 97:1422-1427.

37. Patten, C. L., and Glick, B. R. 2002. Role of Pseudomonas putida indoleacetic acid in development of the host plant root system. Appl. Environ. Microbiol. 68:3795-3801.

38. Salkowski, E. 1885. Ueber das Verhalten der Skatolcarbonsa ure im Organismus. Z. Physiol. Chem. 9:23-33.

39. Saracco, P., Bosco, D., Veratti, F., and Marzachì, C. 2006. Quantification over time of chrysanthemum yellows phytoplasma (16Sr-I) in leaves and roots of the host plant Chrysanthemum carinatum (Schousboe) following inoculation with its insect vector. Physiol. Mol. Plant Pathol. 67:212-219.

40. Sayler, G. S., Fleming, J. T., and Nivens, D. E. 2001. Gene expression monitoring in soils by mRNA analysis and gene lux fusions. Curr. Opin. Biotechnol. 12:455-460.

41. Schmid, M., Schmitz-Esser, S., Jetten, M., and Wagner, M. 2001. 16S$23 \mathrm{~S}$ rDNA intergenic spacer and $23 \mathrm{~S}$ rDNA of anaerobic ammonium- 
oxidizing bacteria: implications for phylogeny and in situ detection. Environ. Microbiol. 3:450-459.

42. Schwyn, B., and Neilands, J. B.. 1987. Universal CAS assay for the detection and determination of siderophores. Anal. Biochem. 160:47-60.

43. Seemüller, E., and Harries, H. 2010. Plant resistance. Pages 147-169 in: Phytoplasmas: Genomes, Plant Hosts and Vectors. P. G. Weintraub and P. Jones, eds. CAB International, Cambridge, MA.

44. Sessitsch, A., Reiter, B., and Berg, G. 2004. Endophytic bacterial communities of field-grown potato plants and their plant-growthpromoting and antagonistic abilities. Can. J. Microbiol. 50:239-249.

45. Sharifi-Tehrani, A., Zala, M., Natsch, A., Moenne-Loccoz, Y., and Defago, G. 1998. Biocontrol of soil-borne fungal plant diseases by 2,4diacetylphloroglucinol-producing fluorescent pseudomonads with different restriction profiles of amplified 16S rDNA. Eur. J. Plant Pathol. 104:631-643.

46. Shrestha, P. M., Kube, M., Reinhardt, R., and Liesack, W. 2008. Transcriptional activity of paddy soil bacterial communities. Environ. Microbiol. 11:960-970.

47. Spaepen, S., Vanderleyden, J., and Remans, R. 2007. Indole-3-acetic acid in microbial and microorganism-plant signaling. FEMS Microbiol. Rev. 31:425-448.

48. Sridevi, M., and Mallaiah, K. V. 2008. Factors effecting chitinase activity of Rhizobium sp. from Sesbania sesban. Biologia 63:307-312.

49. Tassart-Subirats, V., Clair, D., Grenan, S., Boudon-Padieu, E., and Larrue,
J. 2003. Hot water treatment: curing efficiency for phytoplasmas infection and effect on plant multiplication material. Pages 69-70 in: Extended Abstr. 14th ICVG Conf. Locorotondo, Italy.

50. Trotta, A., Varese, G. C., Gnavi, E., Fusconi, A., Sampò, S., and Berta, G. 1996. Interaction between the soil born pathogen Phytophthora parasitica var. parasitica and the arbuscular mycorrhizal fungus Glomus mosseae in tomato plants. Plant Soil 185:199-209.

51. Vandecasteele, S. J., Peetermans, W. E., Merckx, R., and Van Eldere, J. 2001. Quantification of expression of Staphylococcus epidermidis housekeeping genes with Taqman quantitative PCR during in vitro growth and under different conditions. J. Bacteriol. 183:7094-7101.

52. Van Loon, L. C., Bakker, P. A. H. M., and Pieterse, C. M. J. 1998. Systemic resistance induced by rhizosphere bacteria. Annu. Rev. Phytopathol. 36:553-483.

53. Vessey, J. K., Pawlowski, K., and Bergman, B. 2005. Root-based $\mathrm{N}_{2-}$ fixing symbioses: Legumes, actinorhizal plants, Parasponia sp. and cycads. Plant Soil 274:51-78.

54. Weintraub, P. G., and Beanland, L. 2006. Insect vectors of Phytoplasmas. Annu. Rev. Entomol. 51:91-111.

55. Weller, D. M. 1988. Biological control of soilborne plant pathogens in the rhizosphere with bacteria. Annu. Rev. Phytopathol. 26:379-407.

56. Wongkaew, P., and Fletcher, J. 2004. Sugarcane white leaf phytoplasma in tissue culture: Long-term maintenance, transmission, and oxytetracycline remission. Plant Cell Rep. 23:426-434. 